\title{
An Increase in Serum Retinol-Binding Protein 4 in the Type 2 Diabetic Subjects with Nephropathy
}

\author{
MiHo MURATA, TOMOYUKi SAITO, TAEKo OTANI, MASAMI SASAKI, AKI IKOMA, HiDEO TOYOSHIMA, \\ MASANOBU KAWAKAMI AND SAN-E ISHIKAWA
}

Department of Medicine, Jichi Medical University Saitama Medical Center, Saitama, Japan

\begin{abstract}
The present study was undertaken to determine retinol-binding protein 4 (RBP4) levels in subjects with diabetic nephropathy. A total of 149 type 2 diabetic subjects and 19 control subjects were enrolled. Serum levels of RBP4 were measured by a method of ELISA. Serum RBP4 levels were significantly greater in the subjects with type 2 diabetes mellitus than the controls $(70.5 \pm 35.3$ vs. $40.1 \pm 13.0 \mu \mathrm{g} / \mathrm{ml}$, mean $\pm \mathrm{SD}, \mathrm{p}<0.01)$. Serum $\mathrm{RBP} 4$ levels were gradually increased according to the progression of diabetic nephropathy ( $\mathrm{p}$ value in trend test: $<0.001$ ). Its elevation was significantly greater in the diabetic subjects with stages $1,3 \mathrm{~B}$ and 4 than the control subjects (Stage 1: 64.6 \pm 29.7 , Stage 3B: $123.3 \pm 71.8$, Stage 4: $91.4 \pm 33.8$ vs. Control: $40.1 \pm 13.0 \mu \mathrm{g} / \mathrm{ml}, \mathrm{p}<0.01)$. Similar results were obtained in the subjects based on the amount of albuminuria (Normo-: 64.6 \pm 29.7 , Micro-: $63.7 \pm 29.4$, and Marcoalbuminuria: $90.3 \pm 44.6 \mu \mathrm{g} / \mathrm{ml}, \mathrm{p}<0.001)$. Serum RBP4 levels had a positive correlation with serum creatinine levels $(\mathrm{r}=0.377$, $\mathrm{p}<0.001)$, and a negative correlation with $1 /$ creatinine $(\mathrm{r}=-0.420, \mathrm{p}<0.001)$. Also, there was a negative correlation between serum RBP4 and the estimated glomerular filtration rate $(\mathrm{r}=-0.436, \mathrm{p}<0.001)$. Multiple regression analysis showed that estimated glomerular filtration rate was an independent determinant for increased serum RBP4 levels. There was no difference in serum RBP4 levels between the advanced nephropathy with and without macrovascular diseases. These results indicate an increase in serum RBP4 levels in the type 2 diabetic subjects, particularly complicated with advanced renal impairment.
\end{abstract}

Key words: RBP4, Diabetes mellitus, Diabetic nephropathy, Albuminuria, estimated GFR

(Endocrine Journal 56: 287-294, 2009)

RETINOL-BINDING protein 4 (RBP4) is a small protein (molecular weight approximately $21 \mathrm{kDa}$ ), which is synthesized mainly in hepatocytes. RBP4 is also expressed in skeletal muscles and white adipose tissues, that are sensitive to insulin [1]. RBP4 binds to retinol and transthyretin, and delivers to the tissues [2, 3]. It is reported that RBP4 is increased in plasma of subjects with obesity, impaired glucose tolerance and diabetes mellitus [4, 5]. Yang et al. [6] showed that RBP4 is closely linked to insulin resistance in obesity and type 2 diabetes. Alterations in RBP4-transthyretin binding contribute to elevated serum RBP4 levels in

Received: August 29, 2008

Accepted: December 15, 2008

Correspondence to: San-e ISHIKAWA, M.D., Department of Medicine, Jichi Medical University Saitama Medical Center 1847 Amanuma Omiya-ku Saitama, Saitama 330-8503 Japan insulin-resistant states [7]. However, there are several controversial results regarding insulin resistance [813]. In diabetic nephropathy plasma RBP4 levels are further elevated in diabetic subjects with microalbuminuria [14-16].

Diabetic nephropathy is the major microvascular complication of diabetes mellitus, which could progressively develop renal impairment. Endothelial dysfunction may be responsible for accelerated atherosclerosis in chronic kidney diseases. Damaged endothelial cells secrete cytokines and growth factors, and they accumulate into the subendothelial space of the injured region, thus promoting atherogenic change [17-22]. Adipose tissues also produce and secrete many adipokines, including adiponectin, leptin, tumor necrosis factor $\alpha$, RBP4 and others. Among them, they group into 2 types regarding inflammatory and atherogenic effects. It is well known that tumor necro- 
sis factor $\alpha$ has an inflammatory and atherogenic property, whereas adiponectin has an anti-atherogenic and anti-inflammatory adipokine. Because RBP4 may be linked to insulin resistance, it could affect vascular deterioration.

In the present study we determined serum RBP4 levels in the subjects with diabetic nephropathy. Furthermore, we would clarify clinical feature of RBP4 in diabetic nephropathy and related atherosclerotic disorders.

\section{Subjects and Methods}

\section{Subjects}

One hundred forty nine subjects with type 2 diabetes mellitus were enrolled in the present study between March 2005 and January 2007. They were admitted to Jichi Medical University Saitama Medical Center for 2 weeks to learn how and why to treat diabetes mellitus, and also to control their plasma glucose levels practically. They were 78 males and 71 females, with the ages of $63.9 \pm 11.7$ years (mean $\pm \mathrm{SD}$ ) ranging from 18 to 88 years. Ninety-one subjects had hypertension, 90 had hyperlipidemia, and 60 had obesity. Twenty- six subjects had ischemic heart disease, 18 subjects had cerebral vascular disease, and 6 had arteriosclerosis obliterans. According to the progression of nephropathy, the diabetic subjects were divided into stages 1 4 based on the classification of diabetic nephropathy by Research Committee of the Japanese Ministry of Health, Labor and Welfare for Disorders of diabetes mellitus [23]. Namely, stage 1, no microalbuminuria; stage 2 , microalbuminuria ( $>30 \mathrm{mg} / \mathrm{g}$ creatinine, $<300$ $\mathrm{mg} / \mathrm{g}$ creatinine); stage $3 \mathrm{~A}$, macroalbuminuria ( $>300$ $\mathrm{mg} / \mathrm{g}$ creatinine) or positive urinary protein analysis $(<1 \mathrm{~g}$ urinary protein/g creatinine/day); stage 3B, proteinuria $(>1 \mathrm{~g}$ urinary protein/g creatinine/day) and normal serum creatinine level; stage 4, elevated serum creatinine level; and stage 5, under dialysis treatment. The numbers of subjects taking medication for diabetes mellitus, hypertension and hyperlipidemia were summarized in Table 1. Also, 19 age- and gendermatched control subjects were collected from the subjects examining their medical status. They were 11 males and 8 females, with the ages of $59.2 \pm 8.5$ years (mean $\pm \mathrm{SD}$ ) ranging from 46 to 72 years. Eight subjects had hypertension, 11 had hyperlipidemia and 1 had obesity. Also, 3 subjects had ischemic heart disease, 5 subjects had cerebrovascular diseases, and 1 subject had arteriosclerosis obliterans. Blood samples

Table 1. Clinical and laboratory findings in the diabetic patients at the hospitalization

\begin{tabular}{|c|c|c|c|c|c|c|c|}
\hline & \multirow{2}{*}{$\begin{array}{l}\text { Control } \\
\text { subjects }\end{array}$} & \multicolumn{5}{|c|}{ Diabetic patients } & \multirow{2}{*}{$P$ value } \\
\hline & & Stage 1 & Stage 2 & Stage 3A & Stage 3B & Stage 4 & \\
\hline $\mathrm{N}$ & 19 & 85 & 28 & 10 & 7 & 19 & \\
\hline Sex (male/female) & $11 / 8$ & $42 / 43$ & $12 / 16$ & $9 / 1$ & $3 / 4$ & $12 / 7$ & \\
\hline Age (years) & $59.2 \pm 8.5$ & $61.4 \pm 11.5$ & $65.5 \pm 11.8$ & $59.7 \pm 14.3$ & $69.1 \pm 6.0$ & $72.5 \pm 6.9$ & 0.0006 \\
\hline BMI & $23.3 \pm 1.2$ & $24.4 \pm 4.4$ & $25.7 \pm 4.2$ & $24.3 \pm 4.3$ & $24.6 \pm 3.0$ & $25.3 \pm 2.7$ & 0.39 \\
\hline Systolic blood pressure (mmHg) & $132.9 \pm 11.0$ & $132.2 \pm 18.0$ & $138.1 \pm 16.9$ & $147.0 \pm 20.3$ & $139.3 \pm 16.8$ & $135.4 \pm 19.7$ & 0.14 \\
\hline Diastolic blood pressure $(\mathrm{mmHg})$ & $72.8 \pm 8.6$ & $75.1 \pm 10.5$ & $77.6 \pm 9.9$ & $78.8 \pm 12.2$ & $70.1 \pm 8.8$ & $69.6 \pm 10.1$ & 0.063 \\
\hline Total cholesterol (mg/dl) & $203.6 \pm 41.8$ & $209.2 \pm 68.8$ & $203.8 \pm 43.6$ & $203.1 \pm 39.3$ & $235.9 \pm 30.1$ & $180.3 \pm 47.0$ & 0.31 \\
\hline HDL cholesterol (mg/dl) & $47.3 \pm 7.5$ & $46.5 \pm 13.2$ & $50.1 \pm 11.5$ & $46.9 \pm 11.0$ & $48.6 \pm 16.1$ & $44.5 \pm 14.5$ & 0.74 \\
\hline Triglyceride $(\mathrm{mg} / \mathrm{dl})$ & $130.9 \pm 47.6$ & $227.1 \pm 427.7$ & $157.6 \pm 103.2$ & $141.3 \pm 58.9$ & $181.1 \pm 84.3$ & $119.8 \pm 46.3$ & 0.67 \\
\hline Fasting plasma glucose (mg/dl) & $109.3 \pm 10.9$ & $162.3 \pm 56.8$ & $179.1 \pm 54.1$ & $159.3 \pm 62.9$ & $153.0 \pm 65.1$ & $129.7 \pm 50.9$ & 0.0002 \\
\hline $\mathrm{HbAlc}(\%)$ & $5.6 \pm 0.1$ & $8.9 \pm 1.6$ & $9.3 \pm 2.1$ & $9.2 \pm 1.5$ & $8.9 \pm 1.3$ & $8.1 \pm 1.7$ & 0.0067 \\
\hline Creatinine (mg/dl) & $0.70 \pm 0.10$ & $0.65 \pm 0.15$ & $0.64 \pm 0.16$ & $0.77 \pm 0.12$ & $1.00 \pm 0.27$ & $1.25 \pm 0.28$ & $<0.0001$ \\
\hline $1 /$ creatinine & $1.46 \pm 0.19$ & $1.62 \pm 0.41$ & $1.66 \pm 0.43$ & $1.32 \pm 0.18$ & $1.06 \pm 0.26$ & $0.84 \pm 0.18$ & $<0.0001$ \\
\hline Estimated GFR (ml/min/1.73m2) & $87.8 \pm 14.6$ & $84.5 \pm 21.0$ & $84.2 \pm 22.3$ & $76.7 \pm 13.7$ & $48.6 \pm 8.6$ & $40.0 \pm 9.0$ & $<0.0001$ \\
\hline Diabetes mellitus (n) (diet only/drug/insulin) & 0 & $5 / 61 / 19$ & $0 / 15 / 13$ & $2 / 5 / 3$ & $0 / 5 / 3$ & $1 / 9 / 9$ & 0.074 \\
\hline Hypertension (n) (\%) & $8(42.1)$ & $38(44.7)$ & $19(67.9)$ & $9(90)$ & $7(100)$ & $18(94.7)$ & $<0.0001$ \\
\hline Hyperlipidemia (n) (\%) & $11(57.9)$ & $55(64.7)$ & $15(53.6)$ & $3(30)$ & $6(85.7)$ & $11(57.9)$ & 0.22 \\
\hline Ischemic heart disease (IHD) (n) (\%) & $3(15.8)$ & $11(12.9)$ & $4(14.3)$ & $1(10)$ & $2(28.5)$ & $8(42.1)$ & 0.062 \\
\hline Cerebral vascular disease (CVD) (n) (\%) & $5(26.3)$ & $7(8.2)$ & $3(10.7)$ & $3(30)$ & $1(14.2)$ & $4(21.1)$ & 0.154 \\
\hline Arteriosclerosis obliterans (ASO) (n) (\%) & $1(5.3)$ & $1(1.2)$ & $1(3.6)$ & 0 & 0 & $4(21.1)$ & 0.006 \\
\hline
\end{tabular}

Values are mean $\pm \mathrm{SD}$. Values are analyzed by one-way ANOVA or chi-square for independence test. 
were collected from the subjects in the supine position after an overnight fast to determine fasting plasma glucose, hemoglobin Alc, total cholesterol, high-density lipoprotein cholesterol, triglyceride, and serum RBP4 at the time of hospitalization or visiting to the outpatient clinic. Risk factors for atherosclerosis were defined as follows: Dyslipidemia was defined as a total cholesterol of greater than $220 \mathrm{mg} / \mathrm{dl}$, a high-density lipoprotein cholesterol level of less than $40 \mathrm{mg} / \mathrm{dl}$, and a triglyceride level of greater than $150 \mathrm{mg} / \mathrm{dl}$, or the subject's having taken either statins or fibrates. Hypertension was defined as systolic blood pressure of greater than $140 \mathrm{mmHg}$, diastolic pressure of greater than $90 \mathrm{mmHg}$, or the subject's having taken antihypertensive agents. The present study was approved by the ethical committee of Jichi Medical University for human studies. We obtained informed consents from the subjects who joined the present protocol.

\section{Measurements}

Blood samples were collected into tubes and centrifuged at $3,000 \mathrm{rpm}$ at $4^{\circ} \mathrm{C}$ for 15 minutes. The supernatants were decanted and frozen at $-80^{\circ} \mathrm{C}$ until assayed. RBP4 was measured by the method of ELISA using Human RBP4 ELISA kits (AdipoGen, Seoul, Korea). Fasting plasma glucose, hemoglobin A1c, total cholesterol, HDL-cholesterol, triglyceride and creatinine were determined by standard laboratory methods. Urine samples were collected in the morning and 24-hour urine collection was made. Renal function was calculated as the estimated glomerular filtration rate (eGFR) by the Modification of Diet in Renal Disease equation (MDRD) revised for Japanese by the Japan Society of Nephrology: eGFR $\left(\mathrm{ml} / \mathrm{min} / 1.73 \mathrm{~m}^{2}\right)=$ $0.741 \times 175 \times$ age $^{-0.203} \times(\text { serum creatinine }(\mathrm{mg} / \mathrm{dl}))^{-1.154}$ $\times(0.742$, in female $)$.

\section{Statistical analysis}

All values are expressed as means $\pm \mathrm{SD}$. The values were analyzed by one-way ANOVA to compare the difference among the groups. Categorical data were analyzed by the $\chi^{2}$ test. Simple regression analysis was performed to evaluate correlation between the parameters. Also, we checked the independence of parameter by multiple regression analysis. The statistical packages of Statcel Statistical Software (Second Edition, OMS Publishing Inc., Japan) and Mulcel
Statistical Software (First Edition, OMS Publishing Inc., Japan) were employed for the present analysis. A $p$ values less than 0.05 was considered significant.

\section{Results}

We compared clinical features in the diabetic subjects and control subjects (Table 1). Fasting plasma glucose and hemoglobin A1c were elevated in the diabetic subjects as compared to the control subjects ( $p$ value for trend test: 0.0002 and 0.0067 ). The number of hypertensive subjects was increased according to the progression of diabetic nephropathy ( $\mathrm{p}$ value for trend test $<0.0001$ ).

Serum RBP4 levels were increased to $70.5 \pm 35.3$ $\mu \mathrm{g} / \mathrm{ml}$ in all the subjects with type 2 diabetes mellitus, a value significantly greater than that of $40.1 \pm 13.0$ $\mu \mathrm{g} / \mathrm{ml}$ in the control subjects $(\mathrm{p}<0.01)$. Initially, we analyzed serum RBP4 levels in the diabetic subjects according to the amount of albuminuria. Serum RBP4 was significantly increased in the subjects with macroalbuminuria as compared to that in the subjects having normoalbuminuria (Normo-: $64.6 \pm 29.7$, Micro-: $63.7 \pm 29.4$, and Macroalbuminuria: $90.3 \pm 44.6 \mu \mathrm{g} /$ $\mathrm{ml}, \mathrm{p}$ value for trend test $<0.01$ ).

Fig. 1 shows serum RBP4 levels in the diabetic subjects following the stage of nephropathy. According to the progression of diabetic nephropathy, serum RBP4 levels were gradually elevated in the diabetic subjects ( $p$ value for trend test $<0.001$ ). Its elevation was significantly greater in the diabetic subjects with stages 1 , $3 \mathrm{~B}$ and 4 than the control subjects (Control: $40.1 \pm$



Fig. 1. Serum RBP4 levels in the diabetic patients on the classification of nephropathy and the controls. Serum RBP4 levels in the patients with stages 1, 3B and 4 were significantly elevated than the control subjects ( $p$-value for trend test $<0.001)$. Values are means $\pm \mathrm{SD}$. 
Table 2. Linear regression analysis of serum RBP4 levels with varying parameters in the diabetic patients

\begin{tabular}{llcc}
\hline \multicolumn{1}{c}{ Parameters } & $\mathrm{r}$ & $\mathrm{p}$-value \\
\hline RBP4 vs. & Age & 0.199 & 0.015 \\
& BMI & 0.023 & 0.775 \\
& Systolic blood pressure & 0.008 & 0.927 \\
Diastolic blood pressure & -0.128 & 0.12 \\
Total cholesterol & 0.088 & 0.285 \\
HDL-cholesterol & -0.062 & 0.45 \\
Triglyceride & -0.011 & 0.89 \\
Fasting plasma glucose & -0.092 & 0.264 \\
HbA1c & -0.113 & 0.17 \\
HOMA-R & -0.064 & 0.528 \\
Fasting serum insulin & -0.086 & 0.398 \\
Creatinine & 0.377 & $<0.001$ \\
1/Creatinine & -0.42 & $<0.001$ \\
Estimated GFR & -0.436 & $<0.001$ \\
Log (albuminuria) & 0.211 & 0.015 \\
\hline
\end{tabular}



Fig. 2. The relationship of serum RBP4 levels with estimated GFR in the diabetic patients. Serum RBP4 $(\mu \mathrm{g} / \mathrm{ml})=$ $117.6-0.62 \times$ estimated GFR, $r=-0.436, p<0.001$.

$13.0 \mu \mathrm{g} / \mathrm{ml}$ vs. Stage 1: $64.6 \pm 29.7, \mathrm{p}<0.05$, Stage 3B: $123.3 \pm 71.8, \mathrm{p}<0.01$, and Stage 4: $91.4 \pm 33.8 \mu \mathrm{g} / \mathrm{ml}$, $\mathrm{p}<0.01)$.

Table 2 shows the correlation between serum RBP4 levels and varying parameters in the diabetic subjects with nephropathy. Serum RBP4 levels had a positive correlation with serum creatinine levels $(r=0.377$, $\mathrm{p}<0.001$ ), and a negative correlation with $1 /$ creatinine $(\mathrm{r}=-0.420, \mathrm{p}<0.001)$. Fig. 2 depicts the relationship between the estimated glomerular filtration rate (GFR) and serum RBP4 levels in the diabetic subjects. Serum RBP4 levels had a negative correlation with the estimated GFR ( $\mathrm{r}=-0.436, \mathrm{p}<0.001)$. In addition, serum RBP4 levels positively correlated with logtransformed albuminuria. Multiple regression analysis was performed using the following parameters, which were associated with serum RBP4 levels at the $p<0.1$ levels in the simple linear regression analysis (Table 2). Estimated GFR was an independent determinant for increased serum RBP4 levels (standardized coefficient $=-0.466, \mathrm{p}<0.001$ ).

\section{Discussion}

The present study demonstrated that serum RBP4 levels were elevated in the diabetic subjects with nephropathy. eGFR was equivalent in the control subjects and the diabetic subjects with stage 1 , but serum RBP4 levels were significantly increased in the stage 1 diabetic subjects compared with the controls. The marked difference was only the deterioration of plasma glucose control between the stage 1 diabetic subjects and the control. Though it is still not clear that plasma glucose could alter RBP4 level, impaired control of plasma glucose may affect the elevation of serum RBP4 in the diabetic subjects. We analyzed several parameters to clarify the association of serum RBP4 with renal impairment. A significant increase in serum RBP4 was obtained in the subjects with macroalbuminuria, but not in those with normo- and microalbuminuria. Similar study was reported by Raila et al. [14]. They noted that serum RBP4 was increased in patients with microalbuminuria, an early stage of diabetic nephropathy. Similarly, serum RBP4 levels were elevated according to the progression of clinical stages of diabetic nephropathy. They were further elevated in the diabetic subjects with stages $3 \mathrm{~B}$ and 4. Furthermore, serum RBP4 levels had a negative correlation with the estimated GFR in the diabetic subjects. There was a possibility that the discrepancy of the findings from those of previous reports may result from the analysis using different assay kit of RBP4. Ziegelmeier et al. [24] reported a fourfold increase in serum RBP4 levels in patients with chronic hemodialysis compared with control subjects. Their patients included both diabetic and non-diabetic patients. As in the present study the diabetic subjects were admitted to learn how and why control plasma glucose, end-stage kidney disease was not contained in the analysis. Nevertheless, the finding was in concert with that of Ziegelmeier et al. in the end-stage kidney disease. These results indicate an increase in serum RBP4 levels in advanced renal impairment of the diabetic subjects. 
The previous study has suggested that RBP4 is related to insulin resistance in diabetic subjects $[4,5]$. We analyzed linear regression of serum RBP4 with other variables as shown in Table 2. Serum RBP4 did not correlate with either of fasting serum insulin levels and HOMA-R, a finding distinct from the study of Graham et al. [4]. The discrepancy may come from the blood samplings, that is, the blood was collected in a steady state of glucose homeostasis in the non-hospitalized subjects in the study of Graham et al. [4], and it was collected in the hospitalized, poorly controlled subjects in the present study. No relationship of serum RBP4 levels with insulin resistance was also reported by several investigators [8-13]. There was no difference in serum RBP4 levels between the subjects with and without macrovascular diseases. In the subjects with advanced diabetic nephropathy (stages 3 and 4) no difference in serum RBP4 was between the presence and absence of macrovascular diseases. Taken together, there was no evidence that elevation of serum RBP4 is associated with insulin resistance and atherosclerotic changes in the diabetic subjects. However, study limitation of the present analysis was come from the small number of the subjects with atherosclerotic diseases. Further study will be necessary to elucidate the exact relation of RBP4 with atherosclerotic diseases.

RBP4 is the primary carrier for vitamin A (retinol) in plasma and synthesized by the hepatocytes. RBP4 expression is also present in extrahepatic tissues including skeletal muscles and white adipose tissues [1]. It is known that kidney plays a role in maintenance of whole body retinol homeostasis $[25,26]$, which is regulated by glomerular filtration rate and subsequent reabsorption of RBP4 into proximal tubule. The present study showed a negative correlation of serum
RBP4 with the estimated GFR, and an increase in serum RBP4 was apparently found in the advanced diabetic nephropathy. Though the clearance study was not performed, a decrease in GFR could accumulate RBP4 in the systemic circulation [27, 28]. Also, a protein complex of RBP4 bound to transthyretin homotetramer in the systemic circulation may reduce renal clearance of RBP4. Further study will have to be clarified whether kidney actually involves in plasma retinol homeostasis and whether renal-hepatic or renalextrahepatic pathway stimulates the binding of retinol and RBP4.

As shown in Table 2, serum RBP4 levels had significant correlation with age, serum creatinine, 1/ creatinine and estimated GFR. Also, the profound correlation of estimated GFR with serum RBP4 was proven by multiple regression analysis. Either of BMI, plasma glucose control, lipid metabolism and blood pressure did not affect serum RBP4 levels. Also, inflammatory alternations of CRP and IL-18 did not correlate with serum RBP4 levels (data not shown). Thus, metabolic and inflammatory changes did not affect serum RBP4 levels in the diabetic subjects with nephropathy.

In summary, the present study clarified that serum RBP4 levels were increased in the diabetic subjects. According to the progression of diabetic nephropathy, serum RBP4 was gradually elevated. There was a negative correlation between serum RBP4 levels and the estimated GFR. The alteration in serum RBP4 levels did not associate with insulin resistance and macrovascular diseases. The present study indicates an increase in serum RBP4 levels in the type 2 diabetic subjects, particularly complicated with advanced renal impairment.

\section{References}

1. Soprano DR, Soprano KJ, Goodman DS (1986) Retinol-binding protein messenger RNA levels in the liver and in extrahepatic tissues of the rat. J Lipid Res 27: 166-171.

2. Blomhoff R, Green MH, Green JB, Berg T, Norum KR (1991) Vitamin A metabolism: new perspectives on absorption, transport, and storage. Physiol Rev 71: 951-990.

3. Blaner WS (1989) Retinol-binding protein: The serum transport protein for vitamin A. Endocr Rev 10: 308316.
4. Graham TE, Yang Q, Blüher M, Hammarstedt A, Ciaraldi TP, Henry RR, Wason CJ, Oberbach A, Jansson PA, Smith U, Kahn BB (2006) Retinol-binding protein 4 and insulin resistance in lean, obese, and diabetic subjects. $N$ Engl J Med 354: 2552-2563.

5. Janke J, Engeli S, Boschmann M, Adams F, Böhnke J, Luft FC, Sharma AM, Jordan J (2006) Retinol-binding protein 4 in human obesity. Diabetes 55: 2805-2810.

6. Yang Q, Graham TE, Mody N, Preitner F, Peroni OD, Zabolotny JM, Kotani K, Quadro L, Kahn BB (2005) Serum retinol binding protein 4 contributes to insulin 
resistance in obesity and type 2 diabetes. Nature 436: 356-362.

7. Mody N, Graham T, Tsuji Y, Yang Q, Kahn BB (2008) Decreased clearance of serum retinol binding protein and elevated levels of transthyretin in insulin-resistant ob/ob mice. Am J Physiol Endocrinol Metab 294: E785-E793.

8. Stefan N, Hennige AM, Staiger H, Schleicher E, Fritsche A, Häring HU (2007) Circulating retinolbinding protein-4, insulin sensitivity, insulin secretion, and insulin disposition index in obese and nonobese subjects: response to Broch et al. Diabetes Care 30:e91; author reply e92.

9. Promintzer M, Krebs M, Todoric J, Luger A, Bischof MG, Nowotny P, Wagner O, Esterbauer H, Anderwald C (2007) Insulin resistance is unrelated to circulating retinol binding protein and protein $\mathrm{C}$ inhibitor. J Clin Endocrinol Metab 92: 4306-4312.

10. Lewis JG, Shand BI, Elder PA, Scott RS (2008) Plasma retinol-binding protein is unlikely to be a useful marker of insulin resistance. Diabetes Res Clin Pract 80: e13e15.

11. Yao-Borengasser A, Varma V, Bodles AM, Rasouli N, Phanavanh B, Lee MJ, Starks T, Kern LM, Spencer HJ 3rd, Rashidi AA, McGehee RE Jr, Fried SK, Kern PA (2007) Retinol binding protein 4 expression in humans: relationship to insulin resistance, inflammation, and response to pioglitazone. J Clin Endocrinol Metab 92: 2590-2597.

12. Bajzová M, Kovaciková M, Vitková M, Klimcaková E, Polak J, Kovacová Z, Viguerie N, Vedral T, Mikulášek L, Sramková P, Srp A, Hejnová J, Langin D, Stich V. Retinol -binding protein 4 expression in visceral and subcutaneous fat in human obesity. Physiol Res 2007 Nov 30 (Epub ahead of print).

13. von Eynatten M, Lepper PM, Liu D, Lang K, Baumann M, Nawroth PP, Bierhaus A, Dugi KA, Heemann U, Allolio B, Humpert PM (2007) Retinol-binding protein 4 is associated with components of the metabolic syndrome, but not with insulin resistance, in men with type 2 diabetes or coronary artery disease. Diabetologia 50: 1930-1937.

14. Raila J, Henze A, Spranger J, Möhlig M, Pfeiffer AF, Schweigert FJ (2007) Microalbuminuria is a major determinant of elevated plasma retinol-binding protein 4 in type 2 diabetic patients. Kidney Int 72: 505-511.

15. Takebayashi K, Suetsugu M, Wakabayashi S, Aso Y, Inukai T (2007) Retinol binding protein-4 levels and clinical features of type 2 diabetes patients. J Clin Endocrinol Metab 92: 2712-2719.

16. Cabré A, Lázaro I, Girona J, Manzanares J, Marimón F, Plana N, Heras M, Masana L (2007) Retinol-binding protein 4 as a plasma biomarker of renal dysfunction and cardiovascular disease in type 2 diabetes. $J$ Intern Med 262:496-503.
17. Ouchi N, Kihara S, Arita Y, Maeda K, Kuriyama H, Okamoto Y, Hotta K, Nishida M, Takahashi M, Nakamura T, Yamashita S, Funahashi T, Matsuzawa Y (1999) Novel modulator for endothelial adhesion molecules: adipocyte-derived plasma protein adiponectin. Circulation 100:2473-2476.

18. Ouchi N, Kihara S, Arita Y, Nishida M, Matsuyama A, Okamoto Y, Ishigami M, Kuriyama H, Kishida K, Nishizawa H, Hotta K, Muraguchi M, Ohmoto Y, Yamashita S, Funahashi T, Matsuzawa Y (2001) Adipocyte-derived plasma protein, adiponectin, suppresses lipid accumulation and class A scavenger receptor expression in human monocyte-derived macrophages. Circulation 103: 1057-1063.

19. Okamoto Y, Arita Y, Nishida M, Muraguchi M, Ouchi N, Takahashi M, Igura T, Inui Y, Kihara S, Nakamura T, Yamashita S, Miyagawa J, Funahashi T, Matsuzawa Y (2000) An adipocyte-derived plasma protein, adiponectin, adheres to injured vascular walls. Horm Metab Res 32: 47-50.

20. Arita Y, Kihara S, Ouchi N, Maeda K, Kuriyama H, Okamoto Y, Kumada M, Hotta K, Nishida M, Takahashi M, Nakamura T, Shimomura I, Muraguchi M, Ohmoto Y, Funahashi T, Matsuzawa Y (2002) Adipocyte-derived plasma protein adiponectin acts as a platelet-derived growth factor-BB-binding protein and regulates growth factor-induced common postreceptor signal in vascular smooth muscle cell. Circulation 105: 2893-2898.

21. Yokota T, Oritani K, Takahashi I, Ishikawa J, Matsuyama A, Ouchi N, Kihara S, Funahashi T, Tenner AJ, Tomiyama Y, Matsuzawa Y (2000) Adiponectin, a new member of the family of soluble defense collagens, negatively regulates the growth of myelomonocytic progenitors and the functions of macrophages. Blood 96: 1723-1732.

22. Matsuda M, Shimomura I, Sata M, Arita Y, Nishida M, Maeda N, Kumada M, Okamoto Y, Nagaretani H, Nishizawa H, Kishida K, Komuro R, Ouchi N, Kihara S, Nagai R, Funahashi T, Matsuzawa Y (2002) Role of adiponectin in preventing vascular stenosis. The missing link of adipo-vascular axis. J Biol Chem 277: 37487-37491.

23. The research committee of diabetic nephropathy (2001) the renewal of classification by Research Committee of the Japanese Ministry of Health, Labor and Welfare for Disorders of diabetes mellitus. J Jpn Diab Soc 44: 623.

24. Ziegelmeier M, Bachmann A, Seeger J, Lossner U, Kratzsch J, Bluher M, Stumvoll M, Fasshauer M (2007) Serum levels of adipokine retinol-binding protein-4 in relation to renal function. Diabetes Care 30: 2588-2592.

25. Goodman DS (1984) Plasma retinol-binding protein. In: Sporn MB, Roberts AB, Goodman DS (eds) The Retinoids, (Vol 2), Academic Press: Orlando, FL, 
pp. $41-88$.

26. Green MH, Green JB (1994) Dynamics and control of plasma retinol. In: Blomhoff $\mathrm{R}$ (ed). Vitamin A in Health and Disease. Marcel Dekker: New York, Basel, Hong Kong, pp 199-133.

27. Smith FR, Goodman DS (1971) The effects of diseases of the liver, thyroid, and kidneys on the transport of vitamin A in human plasma. J Clin Invest 50: 2426 2436.

28. Vahlquist A, Peterson PA, Wibell L (1973) Metabolism of the vitamin A transporting protein complex. I. Turnover studies in normal persons and in patients with chronic renal failure. Eur J Clin Invest 3: 352-362. 